\title{
Synthesis of $\mathrm{La}_{1-\mathrm{x}} \mathrm{Ca}_{\mathrm{x}} \mathrm{MnO}_{3}(\mathrm{x}=0$ and 0.2$)$ through ultrasonic mixing and its characterisation
}

\author{
Mangasi A $\mathrm{M}^{1}$, Iwan Sugihartono ${ }^{1}$, Teguh $B \mathrm{P}^{1}$, Sitti Ahmiatri Saptari ${ }^{2}$, and Erfan Handoko, ${ }^{1, *}$ \\ ${ }^{1}$ Universitas Negeri Jakarta, Dept. of Physics, Jalan Rawamangun Muka 13220, Jakarta, Indonesia \\ ${ }^{2}$ Universitas Islam Negeri Syarif Hidayatullah, Dept. of Physics, Jakarta, Indonesia
}

\begin{abstract}
In order to investigate the crystal structure and morphology of perovskite manganite materials, we have been successfully synthesized $\mathrm{LaMnO}_{3}$ and $\mathrm{La}_{0,8} \mathrm{Ca}_{0,2} \mathrm{MnO}_{3}$ systems through ultrasonic mixing method. The application of these materials is the alternative cooler technology beside freon gas using with residual emission gas. Stoichiometric mixture of $\mathrm{La}_{2} \mathrm{O}_{3}, \mathrm{MnCO}_{3}$, and $\mathrm{CaO}$ with more than $95 \%$ purity were be prepared by ultrasonic mixing $40 \mathrm{kHz} 60$ watts for 30 minutes to result homogen mixtures. The samples were calcinated at $800^{\circ} \mathrm{C}$ for $1 \mathrm{~h}$ and sintered at $1100^{\circ} \mathrm{C}$ for $3 \mathrm{~h}$. The structure of the samples was examined by Xray diffractometer (XRD) Phillips and result as single phase of perovskite manganite materials. Morphology was studied using a 5310LV Jeol scanning electron microscope (SEM) that show the same grains of perovskite manganite material. While $\mathrm{Ca}$ substituted for $\mathrm{La}$ in the sample, the grain size decreases with decreasing the volume of cell units and finally the particle size of $\mathrm{La} 0.8 \mathrm{Ca} 0.2 \mathrm{MnO}_{3}$ phase decreases.
\end{abstract}

\section{Introduction}

Freon cooling systems have been used by the publicat large. the cooling system produces $\mathrm{CFC}$ gas that can damage Earth'sozone [1-3]. From 1881 to the last few years, research on magnetocaloric effect (MCE) as an alternative technology of freon cooling system [4-9] has been conducted. Broadly speaking, MCE material research is divided in to two composite materials namely metal compounds and oxide compounds. In metal compounds there are three metals that have good MCE value of Gadolinium $(\mathrm{Gd})$, Terbium $(\mathrm{Tb})$, and Dysprosium (Dy) [1]. While the better-known oxide compound perovskite manganite material is a material composition which recently studied that due to have a better value MCE and easily synthesize from the constituent material.This material has the formula of LaxM1-xMnO3 compound with $\mathrm{M}=\mathrm{Li}, \mathrm{Na}, \mathrm{K}, \mathrm{Ca}, \mathrm{Sr}$, $\mathrm{Ba}$, and $\mathrm{Y}$. From several studies which have been done, there is an entropy change of $1.85 \mathrm{~J} / \mathrm{KgK}$ on variation $\mathrm{La}_{\mathrm{x}} \mathrm{M}_{1-\mathrm{x}} \mathrm{MnO}_{3}$ with $\mathrm{Tc}=298 \mathrm{~K}$ [8]. Another case with the

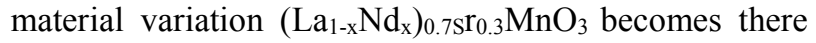
commended material candidate as a cooling material with $\Delta \mathrm{S}=5 \mathrm{~J} /=293 \mathrm{~K}[1,10,11]$. However, a highs intering temperature of about $1250^{\circ} \mathrm{C}$ and a mechanical mixing process is necessary as a condition of solid state reaction to form a manganite perovskite ceramic material. In this paper, the synthesis system $\mathrm{LaMnO}_{3}$ and $\mathrm{La}_{0,8} \mathrm{Ca}_{0,2} \mathrm{MnO}_{3}$ using ultrasonic mixing method with $1100{ }^{\circ} \mathrm{C}$ sintering temperature. The single phase of manganite perovskite material formed and improved microstructure are expected to achieve better results with mechanical mixing methods $[2,3,10,12]$ and can be MCE material candidates.

\section{Experimental procedure}

The perovskite manganite materials of $\mathrm{LaMnO}_{3}$ and $\mathrm{La}_{0,8} \mathrm{Ca}_{0,2} \mathrm{MnO}_{3}$ systems were prepared by ultrasonic mixing method. The mixing process of composite materials $\left(\mathrm{La}_{2} \mathrm{O}_{3}, \mathrm{CaO}\right.$, and $\left.\mathrm{MnCO}_{3}\right)$ with a proportional amount according to their composition stoichiometry in an ultrasonic wave temperature of $40 \mathrm{kHz}$ at 60 watts of power for $30 \mathrm{~min}$ after which it is calcined at a temperature of $800^{\circ} \mathrm{C}$ for 1 hour. For the formation of the phase on the mixture was sintered $1100{ }^{\circ} \mathrm{C}$ for 3 hours after compaction at a pressure of 5 tons diameter of 20 $\mathrm{mm}$. The orthorhombic crystal structured material is measured by Phillips x-ray diffraction $\mathrm{Co}-\mathrm{K} \alpha$ at angle interval (20) $20^{\circ}-100^{\circ}$ data processing with High Score Plus Version 3.0e PANalytical software. Observation of morphology of phase grains using scanning electron microscope (SEM) 5310LV Jeol.

\section{Results and discussion}

The x-ray diffraction pattern of all material constituents in this study is shown in Figure 1a. The identification results provide information that the constituents used have a purity level of more than $95 \%$ and impurities less than $4 \%$ do not appear diffraction peaks. Figure $1 \mathrm{~b}$ is an x-ray diffraction pattern after optimally mixing through the ultrasonic process for both compositions. The same peak pattern shape ensures a homogeneous mixture. Whereas in Fig. 1c is the result after the calcination process at temperature of $800{ }^{\circ} \mathrm{C}$ for 1 hour and shows that all compositions have occurred atomic diffusion which is the formation of manganite perovskite phase.

\footnotetext{
* Corresponding author: mangasi@unj.ac.id; $\underline{\text { erfan@ unj.ac.id }}$
} 

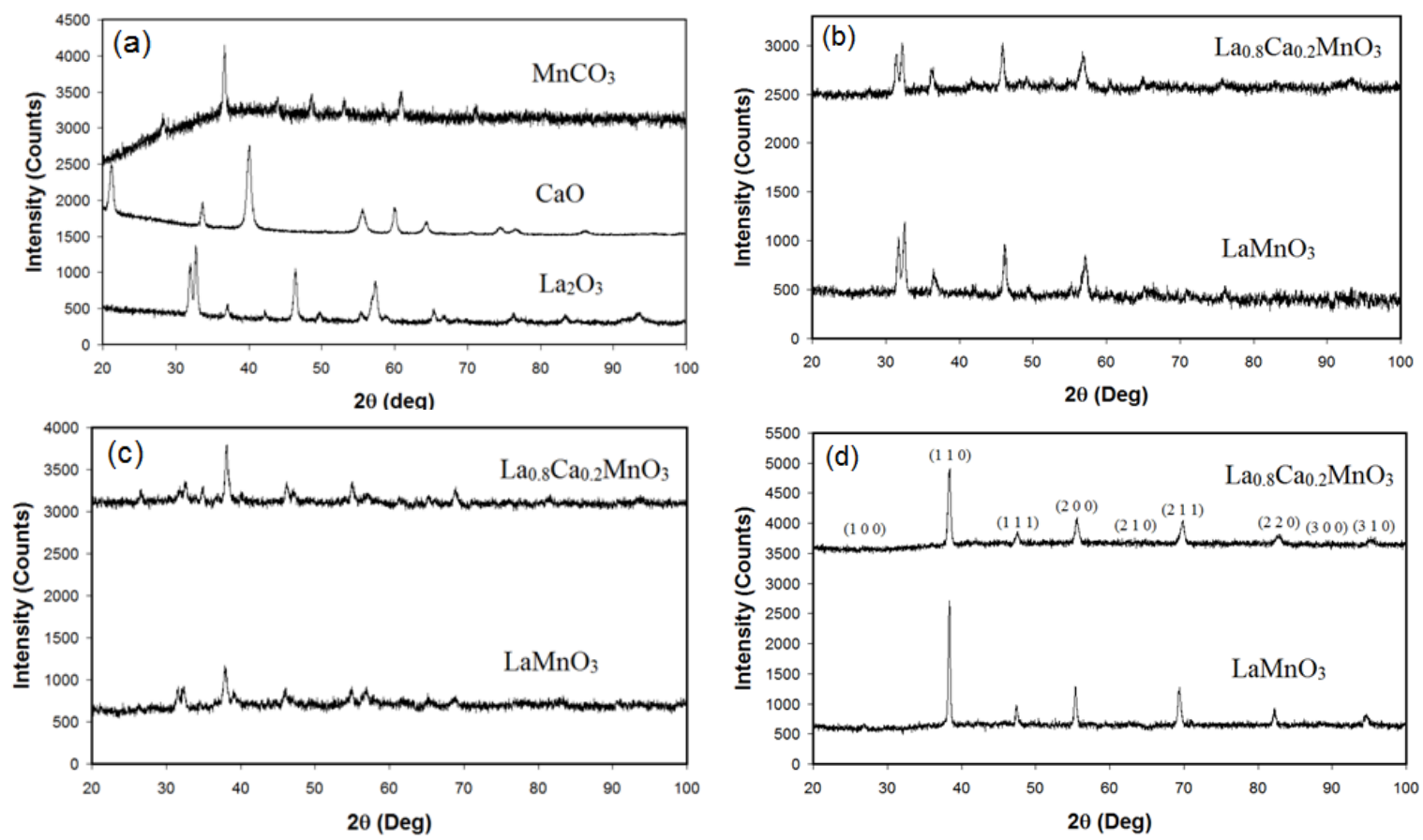

Fig. 1. X-ray diffraction pattern: (a) constituent material, (b) ultrasonic mixing process, (c) calcination process, and (d) after sintering process.

The $1100^{\circ} \mathrm{C}$ sintering process for 3 hours against both compositions of $20 \mathrm{~mm}$ diameter solids ensures that $\mathrm{LaMnO}_{3}$ and $\mathrm{La}_{0,8} \mathrm{Ca}_{0,2} \mathrm{MnO}_{3}$ systems are formed as expected (Figure 1d). The result of qualitative analysis of diffraction pattern in Fig. 1d shows that manganite perovskite phase has been formed for both compositions.
However, there has been a high-intensity difference and there has been a shift to the peak point around the $(2 \theta)$ $38.44^{\circ}$ angle and this also show that there has been $\mathrm{Ca}$ substitution seen from both compositions.
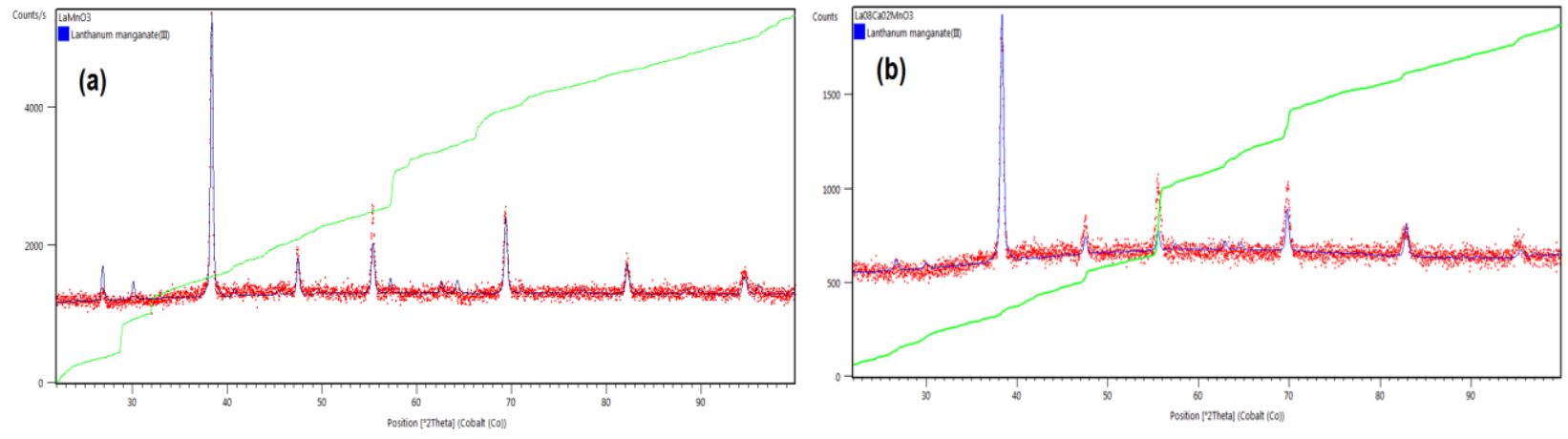

Fig. 2. Refinement results of $x$-ray diffraction pattern data after sintering processfor (a) $\mathrm{LaMnO}_{3}$ and (b) $\mathrm{La}_{0}, 8 \mathrm{Ca} 0,2 \mathrm{MnO}_{3}$.

The results of quantitative analysis of light diffraction data by refinement process (Fig. 2) using the software of HighScore Plus Version 3.0e PANalytical obtained orthorhombic crystal structure with lattice constants respectively $0,545 \mathrm{~nm}(\mathrm{a}), 0,769 \mathrm{~nm}(\mathrm{~b}), 0,544 \mathrm{~nm} \mathrm{c}$ ) for $\mathrm{LaMnO}_{3}$ and $0.539 \mathrm{~nm}$ (a), $0.763 \mathrm{~nm}$ (b), $0.538 \mathrm{~nm}$ (c) for $\mathrm{La}_{0,8} \mathrm{Ca}_{0,2} \mathrm{MnO}_{3}$. There has been a change of constant lattice change due to substitution of $\mathrm{Ca}$ to $\mathrm{La}$ which resulted in the change of unit cell volume to decrease from $0,228 \mathrm{~nm}^{3}$ to $0,222 \mathrm{~nm}^{3}$.

The morphological observations of the microstructure with SEM at 2000 magnification shows the form of particles, which are particles of many crystals (polycrystalline) of different sizes for both compositions. 


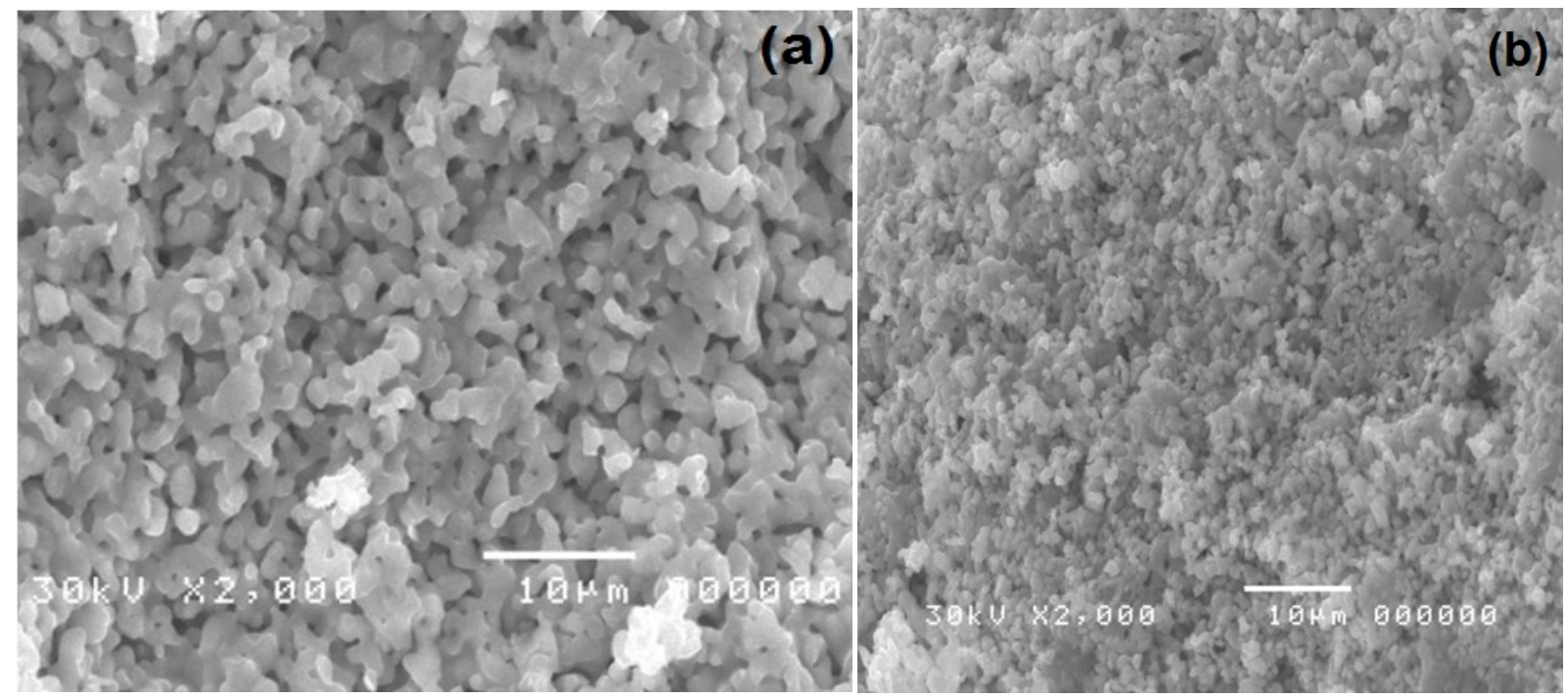

Fig. 3. SEM photographs the microstructure morphology of perovskite materials of the system (a) $\mathrm{LaMnO}_{3}$ and (b) $\mathrm{La}_{0.8} \mathrm{Ca}_{0.2} \mathrm{MnO}_{3}$.

The particle size on a micrometer scale is uniformly homogenous for $\mathrm{LaMnO}_{3}$. However, the effect of $\mathrm{Ca}$ substitution on La resulted in smaller particle size compared to $\mathrm{LaMnO}_{3}$ particle size.This can be as certained as a result of the smaller unit cell volume.In addition supported by the calculation of crystallite size with Scherrer method obtained the average size for 39.4 $\mathrm{nm}$ for $\mathrm{LaMnO}_{3}$ and $28.8 \mathrm{~nm}$ for $\mathrm{La}_{0.8} \mathrm{Ca}_{0.2} \mathrm{MnO}_{3}$.

\section{Conclusions}

In conclusion, the perovskite material of $\mathrm{LaMnO}_{3}$ and $\mathrm{La}_{0,8} \mathrm{Ca}_{0,2} \mathrm{MnO}_{3}$ systems prepared by ultrasonic mixing method has been successfully manufactured and is a polycrystalline material. The focus of the research in the analysis of crystal structure and morphology of microstructure resulted from the formation of single phase manganite perovskite material and the process of substitution of $\mathrm{Ca}$ to La resulted in the change of lattice constants which decrease with the initial cell unit volume of $0,228 \mathrm{~nm}^{3}$ to $0,222 \mathrm{~nm}^{3}$ and also followed by decreasing the crystal size. The decrease in unit cell volume results in a decrease in the size of the grain (cereal grain) after substitution and also based on the morphological observation of the microstructure with SEM the particle size diminishes.

Financial support from hibah DRPM Kemenristek-dikti 2018 is gratefully acknowledged

\section{References}

1. K.A. Gschneider, Jr and V.K. Pecharsky, Annu. Rev. Mater. Sci. 30:387-429. (2000)

2. M.S. Islam, D.T. Hanh, F.A. Khan, M.A. Hakim, D.L. Minh, N.N. Hoang, N.H. Hai, N. Chau. Physica B 404, 2495-2498. (2009)

3. S.K. barik, C. Krishnamoorthi, R. Mahendiran, Journal of Magnetism and Magnetic Materials 323, 1015-1021. (2011)
4. Tishin, AM, Spichkin, YI. (London: Institue of Physics, 2003)

5. K.A. Gschneider, Jr and V.K. Pecharsky, Journal of Applied Physics, Vol. 85, No. 8, (1999)

6. Karl A. Gschneidner, Jr and Vitalij K. Pecharsky. EPD Congress (2002)

7. H. Szymczak, R. Szymczak, Materials SciencePoland, Vol. 26, No. 4, (2008)

8. Jun-Ding Zou, Bao-Gen Shen, Bo Gao, Jun Shen, and Ji-Rong Sun, Adv. Mater, 21, 693-696. (2009)

9. H. Drulis, A. Hackemer, A. Zaleski, Yu.L. Yaropolov, S.A. Nikitin, V.N. Verbetsky,Solid State Communications 151, 1240-1243. (2011)

10. Manh-Huong Phan, Sheng-Bo Tian, Seong-Cho $\mathrm{Yu}$, A.N. Ulyanov, Journal of Magnetism and Magnetic Materials 226 306-310. (2003)

11. Nguyen Hoang Luong, Nguyen Thi Mai Phuong, Phung Thu Hien, Hoang Nam Nhat, Luc Huy Hoang, Nguyen Chau, Nguyen Hoang Hai,

12. VNU Journal of Science,Mathematics - Physics 24 30-35. (2008) 